\title{
EFEKTIVITAS PENERAPAN METODE DISKUSI MKDU - PAK BAGI MAHASISWA UNIVERSITAS NEGERI MANADO
}

\author{
Telly D. Wua
}

\begin{abstract}
Abstrak
Masalah pokok dalam penelitian ini adalah metode mengajar sebagai salah satu teknik untuk membangkitkan perhatian belajar mahasiswa di kelas. Metode mengajar yang dimaksud adalah metode mengajar mata kuliah dasar umum Pendidikan Agama Kristen dalam hal ini yang lebih tepat diterapkan dalam proses belajar mengajar pendidikan Agama Kristen yaitu metode diskusi dengan melihat beberapa cara dan bentuk diskusi yang dapat diterapkan. Desain penelitian yang dipilih adalah: menggunakan pola eksperimen yang dilakukan adalah dengan rancangan 2 x 2 yang. Rancangan (desain) yang dipilih ini adalah rancangan ekperimental yang sebenarnya (sungguhan). Tujuan yang ingin dicapai dalam penelitian ini ialah: (1). Untuk meneliti efektivitas penerapan metode diskusi pada mahasiswa Universitas Negeri Manado, khususnya mahasiswa FIP Jurusan PGSD semester IV UPP I, II, III, yang sedang mengikuti perkuliahan pendidikan agama Kristen. (2). Untuk mengetahui apakah dua kelompok bebas mempunayai perbedaan yang siknifikan dalam hal hasil belajarnya dalam efektivitas penerapan metode diskusi MKDU-PAK. Berdasarkan hasil penelitian dan pembahasannya, maka dapatlah diberikan beberapa pokok pemikiran sebagai kesimpulan dari penelitian ini, seperti berikut: (1). Hasil belajar mahasiswa ditentukan oleh faktor internal mahasiswa itu sendiri baik motivasi, sikap terhadap pelajaran, bakat, IQ, dan sebagainya dan motivasi belajar tersebut banyak dipengaruhi oleh faktor eksternal seperti kebiasaan dalam belajar, disiplin dalam belajar, faktor fasilitas dan lingkungan belajar. (2). Metode mengajar yang tepat untuk suatu proses belajar mengajar mata kuliah banyak mempengaruhi sikap belajar mahasiswa, seperti hal dalam proses belajar mengajar MKDU-PAK. (3). Penerapan metode diskusi dipandang cocok untuk pengajaran pendidikan agama kristen, terutama dalam memecahkan masalah yang membutuhkan perhatian dan semangat dari setiap mahasiswa untuk memecahkan masalah tersebut. (4). Hasil penelitian menunjukkan bahwa antara kelompok eksperimen dan kelompok kontrol untuk efektifitas penerapan metode diskusi baik metode diskusi kelas maupun metode diskusi kelompok MKDU-PAK memberikan pengaruh terhadap hasil belajar mahasiswa, hal ini dapat dilihat pada perbedaan skor atau urutan tingkat yang terjadi. (5). perbedaan urutan tingkat yang terjadi dalam perbedaan hasil antara kelompok diskusi tersebut adalah hal yang sebenarnya, kalaupun terjadi di luar itu merupakan faktor lain. Penelitian ini menyarankan efektifitas pengajaran MKDU-PAK dan mengupayakan pemilihan dan penerapan metode diskusi dengan menyesuaikan materi perkuliahan dengan jenis dan bentuk diskusi apa yang digunakan.
\end{abstract}

Kata Kunci: Metode Diskusi, MKDU-PAK, Mahasiswa 


\section{Pendahuluan}

Kemajuan teknologi, ilmu pengetahuan dan pembangunan membawa pengaruh besar terhadap perkembangan di bidang pendidikan. Tidak terkecuali termasuk didalamnya pendidikan yang dilaksanakan di perguruan tinggi.

Pada dasarnya pendidikan berperan untuk membentuk manusia yang memiliki kepribadian dan kemampuan yang sesuai dengan tuntutan masyarakat dalam pembangunan. Oleh karena itu setiap unsur personil pendidikan dituntut kesadaran dan tanggungjawab yang besar disertai kemampuan dan kepribadian yang kuat dalam melaksanakan pendidikan sehingga tercapai tujuan yang diinginkan.

Mata Kuliah Dasar Umum (MKDU) merupakan kumpulan dari beberapa mata kuliah wajib menjadi kesatuan dengan mata kuliah lainnya diperguruan tinggi dengan tujuan agar dapat menghasilkan warga negara sarjana yang berkualitas:

1. Berjiwa Pancasila, sehingga segala keputusan dan tindakannya mencerminkan pengalaman nilai-nilai Pancasila dan memiliki intergritas kepribadian yang tinggi yang mendahulukan kepentingan nasional dan kemanusiaan,

2. Takwa kepada Tuhan Yang Maha Esa, bersikap dan bertindak sesuai dengan ajarannya dan memiliki tenggang rasa terhadap pemeluk agama lain. (Habib Mustopo, 1989:15).

Pendidikan Agama Kristen adalah salah satu mata kuliah yang termasuk dalam MKDU dan mempunyai tujuan khusus yaitu agar mahasiswa dapat bertumbuh dean membentuk diri seutuhnya sebagai manusia ciptaan baru dalam Yesus Kristus yang dewasa dan bertanggung jawab terhadap Allah, sesama manusia dan lingkungannya.

Dengan demikian mahasiswa akan bersedia mengabdikan seluruh hidup dan segala pekerjaan ilmiahnya untuk kepentingan sesamanya demi hormat dan kemuliaan Allah.

Pendidikan agama Kristen kini merupakan masalah semakin dianggap penting oleh segala gereja Kristen, bahkan gereja-gereja tuapun bergumul dengan masalah ini karena menyadari bahwa suratnya pengaruh dalam masyarakat modern dan berkurangnya semangat Kristen sejati dalam lingkungannya sendir antara lain disebabkan oleh kelemahan dalam mendidik.

Seseorang mahasiswa yang ingin mencapai sukses dalam studinya harus memperhatikan cara-cara atau kebiasaan melakukan studi (belajar), selain mempunyai kebiasaaan pelajaran yang baik juga mempunyai kemampuan kosentrasi belajar dari waktukewaktu dan terutama dalam proses belajar mengajar.

Proses belajar mengajar untuk menghasilkan perubahan dalam diri peserta didik dan mendapatkan ilmu pengetahuan serta menghasilkan pengajaran dengan hasilnya, walaupun tujuan belajar telah dinyatakan dengan jelas dan baik dan belum tentu hasil yang diperoleh itu baik. Sebab itu sesuatu pengajaran disebut baik dan berhasil, jika pengajaran tersebut membangkitkan proses belajar yang efektif. Dalam hal ini masalah yang menentukan bukan sekedar melihat modernnya pengajaran, ataupun prosedur atau konfensionalnya atau profesinya pengajaran, akan tetapi yang dikenakan dalam pengajaran yaitu dengan melihat hasilnya.

Pengajaran pendidikan agama Kristen juga penting untuk menciptakan sistem lingkungan belajar yang efektif dan bermakna, selain dari anaknya kemampuan konsentrasi belajar mahasiswa.

Dalam kenyataan, ada mahasiswa yang memiliki kemampuan dan kosentrasi yang besar juga sebaiknya terdapat mahasiswa yang sukar memusatkan perhatiannya/pikiran terhadap pelajaran, karena terpengaruhi oleh banyak faktor, seperti lingkungan belajar yang tidak memungkinkan, kosentrasi belajar yang sering terganggu, situasi belajar dikelas yang kurang menguntungkan, minat belajar yang kurang, teknik penyajian dosen yang kurang menarik, materi perkuliahan yang kurang sistematis, dan kurang relevan, sehingga mengganggu jalan pikiran atau jalan belajar mengajar yang efektif untuk mendapatkan hasil yang optimal.

Berdasarkan permasalahan yang ada, maka dapatlah dirumuskan masalah seperti: "apakah dengan penerapan metode diskusi dalam pengajaran MKDU-Pendidikan Agama Kristen mampu membangkitkan perhatian dan semangat mahasiswa"? 
Desain penelitian yang dipilih adalah: menggunakan pola eksperimen yang dilakukan adalah dengan rancangan 2 x 2 yang dapat digambarkan sebagai berikut:

\begin{tabular}{|c|c|}
\hline \multicolumn{2}{|c|}{ Penerapan Metode Diskusi } \\
\hline Kelas & Kelompok \\
\hline A & B \\
\hline
\end{tabular}

Rancangan (desain) yang dipilih ini adalah rancangan ekperimental yang sebenarnya (sungguhan), sesuai pedoman buku teknologi penelitian oleh Sumadi Suryabrata, (1983:51).

Dengan dimikian kecenderungan mengenai penerapan kedua metode diskusi akan lebih kuat dengan menggunakan kelompok kontrol, sebagai kelompok pembandingan. Dalam penelitian ini kelompok eksperimen untuk penerapan metode diskusi kelas dan kelompok kontrol dan pembandingan adalah kelompok dengan penerapan metode diskusi kelompok.

\section{Kajian Teori \\ Faktor Menentukan dalam Pendidikan}

Di dalam pendidikan, metode atau cara amat penting. Pengertian metode adalah cara yang teratur dan terpikir baik-baik untuk mencapai maksud dalam ilmu pengetahuan merupakan cara kerja yang bersistem untuk memudahkan pelaksanaan suatu kegiatan guna mencapai tujuan yang ditentukan (KBBI, 1997: 653). M. Nashir Aali (1989), mengatakan bahwa "mendidik adalah pergaulan, maka pergaulan yang mendidik adalah hubungan yang dibentuk dengan satu metode approach yang disadari dengan baik.

Ada beberapa macam metode approach yang biasa dilakukan orang, yaitu: (1) identification approach yaitu metode pendekatan secara mengidentifikasi dari dengan obyek pendidikan. Metode ini sering berhasil membina simpati terhadap anak didik, tetapi terlalu lamban menekankan, menananmkan nilai-nilai pendidikan. Istilah ini M. J. Langevelq dalam buku: "Beknopte Tneoretische Pedagogiek", mengatakan "quasi onwillekeurig" sama dengan sikap pura-pura tak sengaja, yaitu secara pura-pura tak sengaja mampu menangkap situasi-situasi pedagogik yang muncul di tengah proses pergaulan, namun sering sikap begini dianggap tidak efisien karena sering menjadi sentimentil, kabur tujuan dan pendekatan ini hanya terpusat pada anak (child centered orientation). (2). Impresive or normative approach, dimana metode ini memang tidak dapat diterapkan secara konsekuen, tetapi pendidik dapat melaksanakannya, dengan cara berpegang teguh kepada norma-norma yang perlu dari segi pendidikan berdasarkan kekuatan, kemauan sehingga dapat diikuti oleh anak didik. (3). Persuasive approach, yaitu pendekatan secara mengajar dan membujuk. Hal ini secara minimal untuk memberikan hukuman, tetapi lebih banyak memberi hadiah dan lain-lain dan cara ini pula diperkembangkan dengan slogan "tut wuri handayani", mengikut dari belakang sambil mengawasi. (4) Metode Laissez-faire approach yaitu suatu metode yang diartikan masa bodoh terhadap perkembangan anak, tetapi bersikap membiarkan dalam arti anak diiarkan berkembang sendiri, nanti alam akan mendidiknya sendiri. Karena anak itu anak didik sendiri akan bertumbuh mengikuti alam dan metode ini disebut negative approach atau natural education approach disini nampak kadang-kadang kejam karena banyak kali keadaan selalu berubah.

Namun yang dipersoalkan disini ialah bagaimana cara atau metode mengajar yang cocok atau sesuai dengan iklim pengajaran MKDU-PAK yang memiliki kelas yang besar tanpa ditunjang oleh fasilitas yang cukup. Karena tujuan belajar yang baik antara lain di tunjang oleh fasilitas yang cukup. Meminjam pandangan The Liang Gie, (1984) dalam Cara Belajar Yang Efisien, bahwa adanya keteraturan dalam belajar dan cara belajar ditunjang oleh disiplin belajar.

Seorang mahasiswa jika menyadari kesukaran yang dihadapi dalam belajar, hal ini berhubungan dengan cara belajar. Cara belajar yang efisien mengandung asas-asas tertentu yang tidak saja harus dipahami oleh mahasiswa, tetapi lebih dari itu harus dihyati sepanjang masa belajarnya di Perguruan Tinggi. Dalam setia usaha apapun tentu terdapat asas-asas yang harus dijadikan pedoman untuk suksesnya usaha itu, antara lain keteraturan, disiplin dan konsentrasi. Mahasiswa akan memperoleh hasil 
yang baik dengan adanya keteraturan dalam belajar, teratur mengikuti kuliah, teratur dalam menyusun catatan perkuliahan secara teratur dalam hubungannya dengan alat perlengkapan untuk belajar; sebab jika keteraturan ini benarbenar dihayati dan menjadi kebiasaan, maka akan mempengaruhi jalan pikiran karena tidak ada modal yang bernilai daripada suatu pikiran yang teratur untuk menuntut ilmu.

Asas keteraturan dalam belajar itu hendaknya senantiasa menjelma dalam tindakan-tindakan mahasiswa setiap waktu, karena mahasiswa harus setiap hari belajar secara teratur.

Kemudian asas lain dalam belajar yang baik adalah disiplin. Dengan disiplin berarti tujuan belajar akan mudah cicapai. Karena denan jalan berdisiplin untuk melaksanakan pedoman-pedoman yang baik didalam usaha belajar barulah seorang mahasiswa mungkin mempunyai cara belajar yang baik. Sifat malas, ingin cari gampang, segan untuk bersusah payah memusatkan pikiran dalam kuliah, kebiasaan melamun dan kebiasaan lainya yang tidak menunjang belajar sering muncul dalam alam pikiran mahasiswa dikaitkan dengan ketidak disiplinan mahasiswa sudah tentu tujuan kuliah tidak akan tercapai.

Dengan demikian jika mahasiswa telah mempunyai kebiasaan cara belajar yang teratur, disiplin dan banyak melatih akan mudah dalam proses belajar mengajar di dalam kelas.

\section{Metode Mengajar}

Mengajar bertujuan menyampaikan pengetahuan pada anak didik. Pada setiap mengajar selalu dibarengi pemilihan metode dan teknik mengajar. I. L. Pasaribu dan B. Simanjuntak (1986) mengemukakan 11 (sebelas) metode mengajar, yaitu:

1) metode ceramah,

2) metode diskusi,

3) metode tanya-jawab

4) metode kelompok,

5) metode sosiodrama,

6) metode karyawisata,

7) metode pemberian tugas,

8) metode latihan siap,

9) metode pemecahan masalah,

10) metode demonstrasi, dan
11) metode eksperimen.

\section{Metode Diskusi}

Diskusi adalah suatu proses penglihatan dua atau lebih individu yang berinteraksi secara verbal dan salaing berhadapan muka mengenai tujuan atau sasarabn yang sudah tertentu melalui cara tukar menukar informasi, mempertahankan pendapat, atau pemecahan masalah. J.J Hisibuan dan Moedjono (1986), mengemukakan bahwa metode diskusi adalah suatu cara penyajian bahan pelajaran dimana gurumemberi kesempatan kepada siswa (kelompok-kelompok siswa) untuk mengadakan perbincangan ilmiah gunamengumpulkan pendapat, membuat kesimpulan, atau menyusun berbagai alternatif pemecahan atas suatu masalah.

Metode diskusi hanya mungkin timbul jika dihadapi suatu masalah yang memungkinkan bermacam-macam jawaban. Tidak mempunyai hanya satu jawaban yang benar. Setiap jawaban anak beralasan dapat diterima. Bukan suatu debat, dimana seorang berusaha untuk menang dan mempertahankan pendapatnya malah melaksanakan pendapatnya, walaupun bertentangan dengan fakta yang ada.

\section{Jenis-Jenis Diskusi}

Mengutip yang dikemukakan oleh J. J Hasibuan dan Moedjiono bahwa bahwa jenisjenis diskusi dapatlah diklasifikasikanseperti berikut:

1. Whole Group, dimana kelas merupakan satu kelompok diskusi. Whole group yang ideal apabila jumlah anggota tidak lebih dari 15 orang.

2. Buzz Group, yaitu satu kelompok besar dibagi menjadi beberapa kelompok kecil terdiri atas 4-5 orang. Tempat diatur agar siswa dapat berhadapan muka dan bertukar pikiran dengan mudah. Diskusi diadakan ditengah pelajaran atau diakhir pelajaran dengan maksud menajamkan kerangka bahan pelajaran, memperjelas bahan pelajaran atau menjawab pertanyaan-pertanyaan.

3. Panel, Suatu kelompok kecil, biasanya 5-6 orang, mendiskusikan suatu subjek tertentu, duduk dalam suatu susunan semi melingkar, dipimpin seorang mederator. Panel ini secara fisik dapat berhadapan dengan audience, 
dapat juga secara tidak langsung. Pada suatu panel yang murni, audence tidak ikut serta dalam diskusi.

4. Sundicate Group, Suatu kelompok (kelas) dibagi menjadi beberapa kelompok kecil dari 5-7 orang. Masing-masing kelompok kecil melaksanakan tugas tertentu. Guru/dosen menjelaskan garis besarnya problema kepada kelas, ia mengembangkan aspek masalah.

5. Brain Storming Group, Kelompok menyumbangkan ide-ide baru tanpa dinilai segera. Setiap anggota kelompok mengeluarkan pendapatnya. Hasil belajar yang diharapkan adalah anggota kelompok belajar menghargai pendapat orang lain, menumbuhkan rasa percaya kepada diri sendiri dalam mengembangkan ide-ide yang ditemukannya yang dianggap benar.

6. Simposium, Beberapa orang membahas tentang berbagai aspek dari suatu subjek tertentu, dan membacakan dimuka peserta simposium secara singkat (5-20) menit, kemudian diikuti dengan sanggahan dari beberapa pertanyaan dari penyanggah, dari para pendengar, bahasan dan sanggahan itu selanjutnya dirumuskan oleh panitia perumus hasil simposium.

7. Informal Debate, Kelas dibagi menjadi dua tim yang agak sama besarnya dan mendiskusikan subjek yang cocok untuk diperdebatkan tanpa memperhatikan peraturan perdebetan yang formal.

8. Colloquium, Seorang atau beberapa orang manusia sumber menjawab pertanyaan dari audience. Dalam kegiatan belajar mengajar, siswa atau mahasiswa menginterviu manusia sumber, selanjutnya mengundang pertanyaan lain atau tambahan dari siswa atau mahasiswa lain.

9. Fish Bowl, Beberapa orang peserta dipimpin oleh ketua mengadakan suatu diskusi untuk mengambil suatu keputusan. Tempat duduk diatur merupakan setengah lingkaran dengan dua atau tiga kursi kosong menghadap dua peserta diskusi, seolah-olah melihat ikan yang berada dalam sebuah mangkuk (fish bowl), sedang kelompok diskusi berdiskusi kelompok pendengar yang ingin menyumbangkan pikiran dapat masuk duduk di kursi kosong. Apabila ketua diskusi mempersilahkan berbicara, ia dapat langsung berbicara dan meninggalkan kursi setelah selesai berbicara.

Menurut J.J Hasabuan dan Moedijono (1986) diskusi sebagai metode mengajar lebih cocok dan diperlukan apabila guru hendak:

a. Memanfaatkan berbagai kemampuan yang ada pada siswa,

b. memberi kesempatan kepada siswa untuk menyalurkan kemampuannya,

c. mendapatkan belikan dari siswa, apakah tujuan telah tercapai

d. membantu siswa belajar berpikir kritis,

e. membantu siswa belajar menilai kemampuan dan peranan diri sendiri maupun temantemannya (orang lain),

f. membantu menyadari siswa menyadari dan mampu merumuskan berbagai masalah yang dilihat, baik dari pengalaman sendiri maupun dari pelajaran sekolah, dan

g. mengembangkan motivasi untuk belajar lebih lanjut.

Langkah-langkah penggunaan metode diskusi

1. Guru mengemukakan masalah yang akan didiskusikan dan memberikan pengarahan seperlunya mengenai cara-cara pemecahannya.

2. Dengan pempinan guru, para siswa/mahasiswa membentuk kelompokkelompok diskusi, memilih pimpinan diskusi (ketua, sekretaris, pelopor), mengatur tempat duduk, ruangan, sarana dan sebagainya.

3. Para siswa berdiskusi dalam kelompok masing-masing, sedangkan guru berkeliling dari kelompok yang satu ke kelompok yang lain (kalau ada lebih dari satu kelompok) menjaga ketertiban, serta memberikan dorongan dan bantuan agaragar setiap anggota kelompok berpartisipasi aktif, dan agar diskusi berjalan lancar.

4. Kemudian tiap kelompok melaporkan hasil diskusinya.

5. Akhirnya siswa mencatat hasil diskusi dan guru mengumpulkan hasil diskusi dari setiap kelompok. Demikian halnya dalam efektifitas penerapan metode diskusi untuk proses belajar mengajar MKDU-PAK. 


\section{Metodologi Penelitian}

Jenis penelitian berdasarkan produk eksplanasi, dimana kelompok ketegorial dalam menyelesaikan sesuatu tugas dibandingkan deengan kelompok lainnya, dengan demikian pendekatan yang digunakan adalah eksperimen dengan unit studi adalah kelompok.

Pola eksperimen yang dilakukan adalah dengan cara penerapan metode diskusi baik metode diskusi kelas maupun metodee diskusi kelompok. Kelompok eksperimen diterapkan dengan metode diskusi kelas dan kelompok kontrol dengan metode diskusi kelompok.

Sumber data adalah dosen pengajar MKDU khusus mata kuliah Pendidikan agama Kristen dan berbagai alat pengumpul data menggunakan soal-soal tes berdasarkan dokumentasi perkuliahan tersebut.

Populasi adalah seluruh mahasiswa Universita Negeri Manado dan unit sampel adalah mahasiswa Fakultas Ilmu Pendidikan yang beragama Agama Kristen tahun kuliah 2013/2014 sebanyak 137 orang. Anggota sampel diambil $15 \%$ dari unit populasi.

Hal ini berdasarkan pedoman yang dikemukakan oleh Suharsimi Arikunto (1985:107) bahwa jika subyek penelitian lebih daari 100, maka sampel dapat diambil antara 10$15 \%$ tergantung kemampuan peneliti, waktu, tenaga dan dana dan resiko peneliti. Berdasarkan pedoman tersebut, maka dalam penelitian ini diperoleh responden (anggota sampel) sebanyak 20 orang.

Teknik analisis data berdasarkan prosedur tes U mann-Whitney, dengan uji statistik yang digunakan untuk menguji hipotesis: "bahwa kelompok A dan B berbeda hasil belajarnya dalam efektifitas penerapan metode diskusi MKDU-PAK", dimana jika hasil menunjukkan hasil signifikan.

\section{Pembahasan}

Menurut Roestiyak NK bahwa untuk mencapai tujuan Khusu dari setiap mata pelajaran, maka guru memilih, sebab setiap metode mempunyai kelebihan dan kelemahannya sendiri. Karena itu pemilihan metode haruslah berdasarkan pada: sifat dari pelajaran, alat yang tersedia, besar kecilnya kelas, tempat dan lingkungan, kesanggupan guru, banyak sedikitnya materi dan tujuan pengajaran itu sendiri.

Metode diskusi dianggap tempat untuk diterapkan dlam proses belajar mengajar MKDU khusus Pendidikan Agama kristen, sebab metode ini digunakan untuk memecahkan masalah yang tidak dapat dipecahkan dengan satu jawaban saja, karena itu perlunya diskusi agar supaya semua jawaban yang dikehendaki ditampung dan dipertahankan mana yang paling banyak mendekati kebenaran, sehimgga dengan musyawarah dan demokrasi dapat diambil kesimpulan.

Selanjutnya pendidikan Agama kristen dimulai ketika agama itu sendiri mulai muncul dlam hidup manusia.

Tiap-tiap agama di dunia ini mempunyai pendidikannya sendiri $(\mathrm{E} / \mathrm{H}$. Homrighousen and Enklaar dijelaskan bahwa Tuhan Yesus sendiri juga mempergunakan berbagai metode dalam menyampaikan beritaNya, mengenai Kerajaan sorga dan ternyata ia sangat berhasilsebagai seorang guru, bukan ternyata Ia sangat berhasil sebagai guru, bukan saja disebabkan oleh isi pengajaranNya, tetapi juga oleh karena metode/cara yang dipakaiNya (1982:88).

Karena itu setiap guru wwajib menyiapkan diri dengan sebaik-baiknya bukan saja dengan mempelajari materi pelajaran dengan teliti, tetapi dengan melatih diri sesuai dengan pokok yang akan ditetapkan, yang paling sesuai dengan pokok yang akan dibawahnya dan dengan orang-orang yang akan dihadapinya.

Homighousen juga mengatakan bahwa metode adalah suatu pelayanan, suatu pekerjaan yang aktrif yang dilakukan bagi Firman Tuhan dan bagi sesama manusia supaya kedua pihak bertemu satu sama lain. Dengan itu metode hanya jalan dan alat saja bukan tujuan (1982: 92).

Sedangkan I. L. Pasaribu dan B. Simanjuntak mengungkapkan bahwa metode diskusi lelompok ialah untuk memberikan kesempatan kepada para anak didik untuk bertukar pikiran mengenai suatu topik tertentu dan metode ini meuncul pertanyaan yang menarik minat dari siswa (1982, halaman 34). Hal itu lebih diperjelas oleh Homrighousen and Enklaar bahwa metode dikusi adalah cara yang 
amat indah, hasilnya besar jika dijalankan dengan kelompok yang kecil dengan pimpinan yang baik karena yang harus diperhatikan dan dipelajari dari metode ini ialah bahwa guru wajib mengajar murid-murid untuk berpikir sendiri untuk belajar dalam membaca Alkitab dalam mempelajari kepercayaan gereja (1982:94).

Oleh sebab itu dengan penerapan metode diskusi baik diskusi kelas maupun diskusi kelompok maka pemimpin diharapkan mampu menjaga jangan sampai seorang saja yang menguasai percakapan, suasana percakapan itu sebaiknya selaras dengan pertalian Rohani yang menghubungkan anggota kelompok; maksudnya bukan untuk mengalahkan lawan dalam perdebatan akan tetapi supaya membina rohani masing-masing.

Dari hasil penelitian ini ternyata bahwa hasil capai melalaui proses belajar-mengajar dalam efektifitas penerapan metode diskusi dipengaruhi oleh keteraturan belajar, disiplin belajar dari mahasiswa itu sendiri.

Menyadari bahwa diskusi akan berjalan dengan baik apabila mahasiswa telah mengetahui materi apa atau permasalahan yang dibicarakan, tanpa menguasai materi sudah tentu tidak adanya efektifitas dalam proses belajarmengajar terutama dalam memanfaatkan dan menerapkan metode diskusi.

Peneliti berpendapat bahwa penerapan metode diskusi harus ditunjang oleh kepedulian antara mahasiswa dan dosen terhadap permasalahan yang didiskusikan sebab mahasiswa yang tidak mengerti dengan permasalahan, jalan diskusi akan mengarah ke hal yang lain.

\section{Kesimpulan}

Berdasarkan hasil penelitian dan pembahasannya, maka dapatlah diberikan beberapa pokok pemikiran sebagai kesimpulan dari penelitian ini, seperti berikut:

1. Hasil belajar mahasiswa ditentukan oleh faktor internal mahasiswa itu sendiri baik motivasi, sikap terhadap pelajaran, bakat, iQ, dan sebagainya dan motivasi belajar tersebut banyak dipengaruhi oleh faktor eksternal seperti kebiasaan dalam belajar, disiplin dalam belajar, faktor fasilitas dan lingkungan belajar.

2. Metode mengajar yang tepat untuk suatu proses belajar mengajar mata kuliah banyak mempengaruhi sikap belajar mahasiswa, seperti hal dalam proses belajar mengajar MKDU-PAK.

3. Penerapan metode diskusi dipandang cocok untuk pengajaran pendidikan agama kristen, terutama dalam memecahkan masalah yang membutuhkan perhatian dan semangat dari setiap mahasiswa untuk memecahkan masalah tersebut.

4. Hasil penelitian menunjukkan bahwa antara kelompok eksperimen dan kelompok kontrol untuk efektifitas penerapan metode diskusi baik metode diskusi kelas maupun metode diskusi kelompok MKDU-PAK memberikan pengaruh terhadap hasil belajar mahasiswa, hal ini dapat dilihat pada perbedaan skor atau urutan tingkat yang terjadi.

5. Perbedaan urutan tingkat yang terjadi dalam perbedaan hasil antara kelompok diskusi tersebut adalah hal yang sebenarnya, kalaupun terjadi diluar itu merupakan faktor lain.

\section{Saran}

Untuk efektifitas pengajaran MKDU-PAK disarankan kiranya mengupayakan pemilihan dan penerapan metode diskusi dengan menyesuaikan materi perkuliahan dengan jenis dan bentuk diskusi apa yang digunakan.

Namun menjadi pokok permasalahan apabila antara dosen dan mahasiswa tidak menguasai permasalahan (diskusi), sudah jelas akan mempengaruhi efektifitas penerapan metode diskusi, karena itu pentingnya penguasaan materi diskusi. 


\section{Daftar Pustaka}

Hadiwijono, K. Iman Kristen. BPK Gunung Mulia, Jakarta, 1973.

Homrighousen and Enklaar, Pendidikan Agama Kristen, PBK Gunung Mulia, jakarta, 1982,1987.

Mursell, J.L. Mengejar Dengan Sukses, Jemmars, Bandung, 1987.

Nasution, S. Didaktik Asas-asas Mengajar, Jemmars, Bandung, 1980

Rostiah, N. K. Didaktik Metodik Bina Aksara, Jakarta, 1986.

Sanapiah, faisal. Format-format Penelitian Sosial, Rajawali Pers, Jakarta, 1988.

Sudjana, Metode Statistika, Tarsito, Bandung, 1988.

Sumaatmadja, N. Metodologi Pengajaran Ilmu Pengetahuan Sosial, Alumni, Bandung. 1980.

The Liang Gie, Cara Belajar yang Efisien, Gadjah Mada University Press, Yogyakarta, 1984.

Verkuyl, J. Mahasiswa Bertanggung Jawab. BPK Gunung Mulia, Jakarta, 1982.

W. Nashir Ali, Dasar-dasar Ilmu Mendidik, Mutiara, Jakarta, 1979.

Winarno, S. Metodologi Pengajaran Nasional. Jemmars, Bandung. TT 